Research letter

\title{
The spread of tuberculosis in the student milieu of Russian emigrants in Czechoslovakia in the 1920s: statistics, control measures, outcomes
}

\author{
Lyudmila V. Klimovich ${ }^{1}$, Valeriy V. Suvorov ${ }^{2}$ \\ ${ }^{1}$ Ulyanov State Pedagogical University, Ulyanovsk, Russia \\ ${ }^{2}$ Saratov State Medical University, Saratov, Russia
}

Received 4 September 2019, Revised 7 November 2019, Accepted 25 November 2019

(C) 2019, Klimovich L.V., Suvorov V.V.

(C) 2019, Russian Open Medical Journal

Abstract: The article is devoted to the analysis of the health status of emigrant students from Russia who lived in the Republic of Czechoslovakia in the 1920s. Special attention is paid to the spread of tuberculosis among students. The author gives the information about the ratio of sick students, severe cases, and lethal outcomes. It has been pointed out that death from tuberculosis accounted for $50 \%$ of all lethal outcomes. The data obtained gave grounds to draw a conclusion that the incidence rate of tuberculosis among students was high. There were cases of tuberculosis of bones and joints, the presence of malignant tumors. The author traced the relationship between a student's academic performance and his illness.

The article describes the methods used by the medical commission to reduce the number of severe cases: summer sanatoriums, colonies for ill students. The paper also describes control measures taken both at the government level and at the level of public activity of the emigrant community. The Committee on Tuberculosis Control in the Society of Russian Doctors in the Republic of Czechoslovakia made a contribution to the cause of preserving the life and health of students. The paper is based on archival materials from the records of the Committee on Education of Russian and Ukrainian Students in the Republic of Czechoslovakia in the National Archives of the Czech Republic.

Keywords: Russian emigration, Czechoslovakia, tuberculosis, health, migrants, Committee on Tuberculosis Control in the Society of Russian doctors in the Republic of Czechoslovakia, D.P. Kishensky

Cite as Klimovich LV, Suvorov VV. The spread of tuberculosis in the student milieu of Russian emigrants in Czechoslovakia in the 1920s: statistics, control measures, outcomes. Russian Open Medical Journal 2019; 8: e0414.

Correspondence to Lyudmila V. Klimovich. Phone: +79022103720. E-mail: lusek84@yandex.ru.

\section{Introduction}

Today, tuberculosis is one of the top ten causes of death in the world. It poses a serious medical problem and requires increased attention [1]. At the same time, one of the main problems that European countries encounter is morbidity among migrants, including illegal ones.

The success of the fight against tuberculosis in the second half of the 20th century and the beginning of the 21st century shows positive dynamics. The mortality rate in 2017 in the Czech Republic was 0.4 per 100,000 people [2], and cases of tuberculosis decreased from 16 in 2000 to 5.4 in 2017 per 100,000 people [3]. Moreover, the rise in the incidence of tuberculosis in the early 2000s was often associated with illegal migrants from Russia, Ukraine and other countries of the former USSR [4;5]. The Czech Republic is one of the countries where compared with the indigenous people, the high risk of poor health is observed not only among migrants of the first and second generation, but also among "diplomats' children" and re-emigrants [6].

However, Czechoslovakia faced the problem of tuberculosis incidence among migrants back in the interwar period, when after the revolution of 1917 and the civil war, a part of Russian society began to emigrate to Europe. Despite the much smaller development of methods of treatment and prevention of tuberculosis than at present, the efforts of Russian and Czechoslovak doctors, as well as with the support of the Czechoslovak government, contributed to curbing the incidence and mortality from tuberculosis among the Russian emigration at the level of the indigenous European population.

Health was a fundamental factor in the reproduction of the emigrant community. The younger generation of emigrants in many respects determined the image of the Russian diaspora, and the state of its health was an important parameter in building one's personal life and social activity. Nevertheless, the health issues of Russian emigrants, young people in particular, did not attract the researchers' attention, and the problem of the spread of tuberculosis among emigrant students was not the subject of a separate study.

The problem of tuberculosis among emigrant youth is included in the world problem of tuberculosis control. All this determines the topicality and scientific importance of addressing the specific features of the incidence of tuberculosis, control measures and its outcomes in the youth milieu of Russian emigration in the 1920s. 


\section{Material and Methods}

The problems of the spread of tuberculosis in Czechoslovakia were dealt with in a number of works devoted to the development of measures to fight it and their results [7-12].

The paper is based on professor D.P. Kishensky's report on the state of health among Russian students of higher education institutions of the Republic of Czechoslovakia (tuberculosis diseases, nervous and mental diseases), which was made public in the mid-1920s. The documents, which were used to write this paper, are kept in the records of the Committee on Education of Russian and Ukrainian students in the Czechoslovak Republic in the National Archives of the Czech Republic.

The main method is the analysis of statistical data, which archival documents contained. The comparative historical approach allowed us to integrate the problem of the spread of tuberculosis among the younger generation of Russian emigrants into the general situation in Czechoslovakia.

\section{Results and Discussion}

In the first half of the XX century, tuberculosis was one of the main causes of mortality, both in Russia and in Europe [13]. Prevention and treatment of the disease required resources and control at the government level. In World War I, mortality from tuberculosis in the young male population aged from 15 to 30 took a sharp upturn, gradually decreased in the 1920s and averaged in European countries from 100 to 200 deaths per 100,000 people (which corresponded to $0.1-0.2 \%$ ) and remained at that level till the beginning of World War II [14].

During the first half of the 20th century, tuberculosis was a serious problem in Czechoslovakia; the mortality rate from it was one of the highest in Europe [15]. In 1919, the death rate from tuberculosis was 360 cases per 100,000 people, decreasing in 1938 to 127 deaths per 100,000 people [16]. Statistical data on morbidity was not collected in the 1920s [15].

In order to establish a unifying organization to fight tuberculosis throughout the territory of the newly formed state, the Masarykova League against tuberculosis (Masarykova Liga proti tuberkulose) was founded in 1920. Awareness raising and educational activities, patient care, infection prevention were the main areas of work of the Masaryk League against tuberculosis. With the discovery of the tuberculosis vaccine, the number of lethal outcomes declined sharply [17].

Russian emigrants, having become refugees after 1917, needed attention and medical control, especially the younger generation. Russian citizens came to Europe through different routes. The major part of General Vrangel's army units was evacuated through Constantinople. In its ports, there were about 150 thousand people at the end of 1920 [18]. The resolution of the issue where to house refugees took two weeks. At that time they were on ships, then they were placed in military camps. Conditions of housing, crowds of people in one place, unbalanced nutrition contributed to a decrease in immunity and the spread of diseases, among which tuberculosis was number one: "Military units were mainly housed in dilapidated barracks and just tents - the only refuge even in the winter. Mass diseases and lack of medicines led to the fact that 250 people died in the first two winter months" [18]. About 27 thousand refugees were accepted by the Kingdom of Serbs, Croats and Slovenes. The rest part followed to other European countries, including Czechoslovakia, the government of which invited young people from Russia to get higher education in their educational institutions. Difficulties with employment, low salaries did not allow emigrants to provide support for their families and normal living conditions. The younger generation, that did not have time to get education in Russia and had no work experience, encountered more difficulties. Researchers point out that these factors determined a low level of married people and a high percentage of unmarried men [19].

In Czechoslovakia, with the support of the government, the Association of Russian Municipal and Urban Representatives in the Czechoslovak Republic (Zemgor) was organized in 1921 in the framework of the "Russian Aid Campaign". One of the areas of its activity was the organization of outpatient treatment, giving out free medications and treatment allowances in sanatoriums. On September 15, 1923 a hospital was opened for 60 tuberculosis patients thanks to the efforts of Zemgor that continued the traditions of pre-revolutionary Russian municipal and urban selfgovernment bodies, including in the matters of healthcare organization [20].

In the 1920s, the Society of Russian Doctors in Czechoslovakia was established and operated. It was composed of well-known doctors and scientists from the emigrant community. In the early 1920s, recognizing the complexity of medical support and the meager possibilities of caring for one's health, the Committee on Tuberculosis Control was set up in the Society of Russian Doctors. Its active participant, and then its chairman was Professor D.P. Kishensky, doctor of medicine, who defended his doctoral dissertation in 1894, entitled "The influence of abdominal incision on peritoneal tuberculosis" and later headed Novorossiysk University in Odessa. Since 1923, he had been living in Czechoslovakia. He was the chairman of the medical department of the Board of Education and the chief physician of the Committee on Education of Russian Students in Czechoslovakia (since 1926, the Committee on Education of Russian and Ukrainian Students in Czechoslovakia), he headed the Committee on Tuberculosis Control.

Many Russian doctors from the emigrant community made a significant contribution to maintaining their compatriots' health. In Prague former military doctor I.I. Krasheninnikov worked in the outpatient clinic of the Russian Society of the Red Cross (an old organization). He was the treasurer of the Society of Russian Doctors in Czechoslovakia (SRDCS) and was a member of the Presidium of the Committee on Tuberculosis Control. A wellknown specialist in pulmonary diseases, Isaac Naumovich Altshuller, a doctor of A.P. Chekhov, L.N. Tolstoy, one of the founders of the International League for the Fight against Tuberculosis, worked in Prague. Being in exile, he continued his research and medical assistance to Russian refugees. Professor Sergey Sergeyevich Gruzdev since 1924 he had been living in Czechoslovakia and was responsible for providing assistance to students.

At the beginning of the 1920s, the Czechoslovak government invited Russian emigrant youth to get higher education at universities of the young republic. Two dormitories were provided for living: Slobodarna and Khudobintse. There was an infirmary in the dormitory Slobodarna, the condition of which was unsatisfactory. Professor D.P. Kishensky in his report in February 1925 pointed out that there was no ventilation in the infirmary, hot water in the bathroom, a dirty toilet and poor nutrition of patients did not contribute to the restoration of students' health 
[21]. Students wrote about the situation in the infirmary back in 1922: "Students are housed in rooms of $12-15$ people, living in crowded conditions. With the exception of beds, there is no furniture available ... students are currently washing themselves in the open air in the garden, or they go to a mountain river 100-150 $\mathrm{m}$ from the colony" [22].

In Czechoslovakia, thanks to the support of the government and the Czech Red Cross Committee, regular medical check-ups of students among Russian emigrants were carried out. The medical department of the Board of Education of the Committee on Education of Russian Students in Czechoslovakia under the guidance of professor D.P. Kishensky did regular medical check-ups of low-performing students, according to the results of which, decisions were made to give benefits for their learning: "starting with the postponement of exams without losing a semester and ending with the loss of a semester" [23]. According to the report of the medical commission for the examination of low-performing students (from January 1, 1925 to January 1, 1926), out of 161 students examined in 1925, 51\% were ill with tuberculosis, 78 had pulmonary tuberculosis, and 4 had spinal tuberculosis [23]

The information on the spread and control of tuberculosis is contained in D.P. Kishensky's report on the state of health among Russian students in higher educational institutions of the Czechoslovak Republic. The report was heard at a meeting of the Board of Education on July 27, 1926. However, this report, according to the professor himself, did not give a complete picture of the spread of tuberculosis among students: "in order to get a complete picture of the spread of this disease among Russian students, a thorough, attentive and competent medical examination is necessary, which under the present conditions is completely impossible" [24].

In the period between 1923-1926, of 2,133 Russian students who studied at universities of Czechoslovakia, cases of tuberculosis were found in 510 people, which amounted to $24 \%$ of the total number of students. In the course of the medical examination of 444 students, the number of people who had tuberculosis already reached $53 \%$ [24].

The data that professor D. P. Kishensky had, showed that "the number of seriously ill Russian students was very large, in the vast majority of cases they had tuberculosis" [24]. The report emphasizes that students rarely sought medical aid, "only in case of emergency, and some of them only in case of failure in their academic affairs" [24]. The percentage of tuberculosis incidence in Prague among students from Russia was approximately $40-50 \%$.

Being aware of the seriousness of the spread of tuberculosis, socially active members of emigration decided to collect a monthly contribution to the support fund for tuberculosis patients among Russian emigrants. Student organizations did not stand aside, so the contribution from the professor was 10 korun, from doctors and engineers 5 korun, students paid 2 korun per month [25]. Owing to these contributions, in 1923 a summer camp for 50 people was provided, in 1924125 people were able to improve their health, 30 people were placed in a permanent sanatorium.

Despite the measures taken to control tuberculosis, it remained one of the leading causes of death. Between 1922 and 1926, 62 students died, 37 of whom died from pulmonary tuberculosis: "the number of deaths from pulmonary tuberculosis exceeds the number of deaths from all other causes" [24]. But this is not a high rate, taking account that 87 people had severe forms of pulmonary tuberculosis (stages 2 and 3 ), and the total number of registered cases of tuberculosis was 510 . Thus, the mortality rate from tuberculosis was about $7 \%$. In addition to pulmonary tuberculosis, cases of bone and joint tuberculosis were recorded in 14 people, 8 of whom suffered from spinal tuberculosis.

The medical commission headed by Professor D.P. Kishensky emphasized the importance of diagnosing the disease: $x$-ray, auscultation and percussion. They also paid attention to the first signs of the manifestation of the disease: anemia, weight loss, without any changes in the lung tissue. The state of health inevitably affected students' academic performance. Doctors stated that "the majority of students with poor academic performance suffer precisely from pulmonary tuberculosis" [24].

The problem of tuberculosis disease was also relevant among school students of "Russian schools". In the first years of emigration in 1923-1924, out of 197 school students from the Russian Reformed Grammar School in Prague, 12 people were diagnosed with varying degrees of severity and one child died [26]. In the 1927-1928 school years, there were 7 people out of 281 students with tuberculosis; no deaths were mentioned [27]. Thus, we can talk about a decrease in the incidence of tuberculosis among children and adolescents from $7.5 \%$ to $2.4 \%$.

Regular medical check-ups of students helped to diagnose the disease at the initial stage, which allowed the authorities to take measures to provide treatment and recovery. The tuberculosis program carried out by the Czechoslovak government also affected the Russian emigrant community. Owing to comprehensive measures, it was possible to reduce the number of cases of tuberculosis and reduce the number of lethal outcomes.

\section{Conclusion}

A specific feature of Russian emigration of the 1920s was a high degree of its self-organization, manifested, inter alia, in the fields of medicine and healthcare and dating back to prerevolutionary traditions. Along with the efforts of the Czechoslovak authorities, emigrant doctors themselves actively participated in the organization of treatment and prevention of tuberculosis. The death rate from tuberculosis among Russian emigrants was twice as high as among residents of Czechoslovakia. This was due to the conditions of refugee life, unsettled life, a difficult financial situation that did not allow them to have good nutrition and look after their health. Owing to the support of the Czechoslovak government, a health resort for tuberculosis patients was established, funds were allocated for treatment of children and youth in sanatoriums, regular medical check-ups of school students and students were carried out, which made it possible to identify the disease in the early stages. A high level of culture and education allowed Russian emigrants to cope with diseases effectively.

\section{Conflict of Interest}

The authors declare that they have no conflict of interest.

\section{Funding}

The reported study was funded by the grant of the President of the Russian Federation, project number MK-2144.2018.6

\section{References}

1. WHO. Fact sheets. Tuberculosis. 2019. https://www.who.int/newsroom/fact-sheets/detail/tuberculosis. 
2. WHO. Czechia: Tuberculosis profile. 2019. https://extranet.who.int/sree/Reports?op=Replet\&name=\%2FWHO H Q Reports\%2FG2\%2FPROD\%2FEXT\%2FTBCountryProfile\&ISO2=CZ\&LA $\mathrm{N}=\mathrm{EN} \&$ outtype $=\mathrm{html}$.

3. Incidence of tuberculosis (per 100,000 people) - Czech Republic. World Health Organization, Global Tuberculosis Report. https://data.worldbank.org/indicator/SH.TBS.INCD?display=graph-$>$ \&end $=2017$ \&locations $=C Z \&$ start $=2000 \&$ view $=$ chart.

4. Willoughby I. Concern about the return of tuberculosis to Czech Republic. Czech Radio 7, Radio Prague International 2004. https://www.radio.cz/en/section/ice_special/concern-about-thereturn-of-tuberculosis-to-czech-republic.

5. Basic Overview of Tuberculosis Epidemiology in the Czech Republic in 2018. Prague: Institute of Health Information and Statistics of the Czech Republic, 2018. http://www.uzis.cz/en/system/files/tbc2018_en_A2b.pdf.

6. Kislitsyna OA. Health differences between migrants and indigenous population in Russia and other countries of European region. Social aspects of population health 2013; (3 (31)): 1-20. Russian. https://elibrary.ru/item.asp?id=19399048.

7. Virsík K, Bajan A. Development and achievements of tuberculosis and respiratory disease control in Czechoslovakia in the last 30-years. Cas Lek Cesk 1975; 114(33): 1001-1002. Slovak. https://www.ncbi.nlm.nih.gov/pubmed/1164716.

8. Kótyuk E. Healthcare in the Trans-Carpatian Region in the Czechoslovakian era (1919-1939). Orvostort Kozl 2007; 52(1-2): 61-69. German. https://www.ncbi.nlm.nih.gov/pubmed/18175536.

9. Trefny J, Hejdova E. Model of the epidemiology of tuberculosis in the Czech Socialist Republic. Bull Int Union Tuberc 1982; 57(3-4): 212-217. French. https://www.ncbi.n/m.nih.gov/pubmed/7168810.

10. Trnka L, Danková D. Tuberculosis control in Czechoslovakia in 1987. Cas Lek Cesk 1989; 128(26): 809-813. Czech. https://www.ncbi.nlm.nih.gov/pubmed/2790873.

11. Dankova D, Trnka L. The tuberculosis surveillance system in Czechoslovakia. Bull Int Union Tuberc Lung Dis 1989; 64(1): 15-16. https://www.ncbi.nlm.nih.gov/pubmed/2743039.

12. Vargová L, Vymazalová K., Horáčková L. A brief history of tuberculosis in the Czech Lands. Tuberculosis (Edinb) 2017; 105: 35-48. https://doi.org/10.1016/j.tube.2017.04.006.

13. Murray JF, Schraufnagel DE, Hopewell PC. Treatment of Tuberculosis. A Historical Perspective. Ann Am Thorac Soc 2015; 12(12): 1749-1759. https://doi.org/10.1513/AnnalsATS.201509-632PS.

14. Perelman MI (ed). Phthisiology. Moscow: GEOTAR-Media, 2010; 512 p. https://www.rosmedlib.ru/book/ISBN9785970412329.html.

15. Kubín M. Začátky a konce Masarykovy ligy proti tuberkulóze. III. díl. Kazuistiky v alergologii, pneumologii a ORL 2013; 10(3): 32-34. Czech. http://www.medvik.cz/link/bmc14043869.

16. Kubín M. Začátky a konce Masarykovy ligy proti tuberkulóze. I. díl. Kazuistiky v alergologii, pneumologii a ORL 2013; 10(1): 26-30. Czech. http://www.medvik.cz/link/bmc13018327.

17. Adamus J. Tuberkulóza v agendě Národních listů 1861-1929. Diplomová práce. Praha, 2016; 75 p. Czech. http://hdl.handle.net/20.500.11956/31248.

18. Uturgauli SN. White Russians in the Bosphorus. 1919-1929. Moscow: Institute of Oriental Studies, RAS, 2013; 328 p. Russian. http://book.ivran.ru/book?id=244\&from=1.

19. Klimovich LV, Kovaleva DN. A Social and Cultural Profile of the Younger Generation of the Russian Emigration in the 1920-1930s Based on the Documents of the Archive of Yugoslavia. Balkanistic forum 2019; 2: 4659. https://elibrary.ru/item. asp?id=37559987.

20. Andriyanova EA, Zavialov AI, Rajkova SV, Suvorov VV. The contribution of medical communities and rural doctors to the development of sanitary care in the Saratov Province in the second half of the 19th and the beginning of the 20th century. History of Medicine 2018; 5(4): 278285. https://doi.org/10.3897/hmj.5.4.35688.
21. Report No. 3 at a meeting of the Medical Department on February 11 1925 and at a meeting of the Council of the Board of Education with representatives of the Ministry of Foreign Affairs and the Czechoslovak Red Cross. National Archive of the Czech Republic (Národni Archiv ČR). F.746. Ka 4. Inv. 47.

22. A letter from student Zelensky to Mr. Colonel [it was impossible to identify the addressee] dated 09.09.1922. National Archives of the Czech Republic (Národni Archiv ČR). F.746. Ka 4. Inv. 47.

23. The report of the medical commission for the examination of low performing students (from January 1, 1925 to January 1, 1926). National Archive of the Czech Republic (Národni Archiv ČR). F.746. Ka 4. Inv. 47.

24. D.P. Kishensky's report on the state of health of Russian students in higher educational institutions of the Czechoslovak Republic (tuberculosis diseases. Nervous and mental illnesses. Medical care). The report was heard at a meeting of the Council of the Board of Education on July 27, 1926. National Archives of the Czech Republic (Národni Archiv ČR). F.746. Ka 4. Inv. 47.

25. A letter of G.Ya. Troshin, the chairman of the Committee on Tuberculosis Control in the Society of Russian Doctors in the Republic of Czechoslovakia to Professor A.I. Glazunov, a member of the Board of Education dated June 27, 1924. № 65 National Archives of the Czech Republic (Národni Archiv ČR). F.746. Ka 4. Inv. 47.

26. The report about the Russian reformed grammar school in Prague for the 1923-1924 academic years. Proprietary edition. Printed by "Legiongraphy" in Prague.1924. National Archives of the Czech Republic (Národni Archiv ČR). F. 908. Ka. 39.

27. The report about the Russian reformed grammar school in Prague for the 1927-1928 academic years. Prague. 1928. National Archives of the Czech Republic (Národni Archiv ČR). F. 908. Ka. 106.

\section{Authors:}

Lyudmila V. Klimovich - PhD, Associate Professor, Department of History, Ulyanov State Pedagogical University, Ulyanovsk, Russia. https://orcid.org/0000-0003-3541-7159.

Valeriy V. Suvorov - PhD, Researcher, Museum of History, Saratov State Medical University, Saratov, Russia. https://orcid.org/0000-0002-4181$\underline{9034}$ 